\title{
Randomised trial of azithromycin versus ofloxacin for the treatment of Typhoid fever in adult
}

\author{
Nguyen Thi Ly ${ }^{1}$, Nguyen Tran Chinh ${ }^{1}$, C.M. Parry², To Song Diep ${ }^{3}$, J. Wain ${ }^{2}$, N.J. White ${ }^{2}$
}

\begin{abstract}
Abstrak
Selama beberapa tahun terakhir telah timbul galur kuman Salmonella typhi yang resisten terhadap berbagai jenis antibiotika (MDR) di berbagai negara termasuk Vietnam. Di Vietnam dan anak benua India juga ditemukan adanya isolat S. typhi yang resisten terhadap asam nalidiksat yang disertai berkurangnya sensitifitas terhadap obat fluorokuinolon. Sefalosporin generasi ketiga dan fluorokuinolon merupakan obat-obat yang sering dipergunakan untuk pengobatan demam tifoid (DT) pada masa kini. Azitromisin (AZM) mempunyai aktifitas sedang terhadap S. typhi, tetapi dapat mencapai konsentrasi intraseluler yang tinggi dan terbukti efektif untuk pengobatan DT bila diberikan selama 7 hari atau lebih lama. Tidak didapatkan adanya suatu hasil penggunaan jangka pengobatan AZM yang lebih pendek yang dilakukan secara acak. Lima penderita dewasa dari Vietnam dengan hasil biakan yang positif diikutsertakan dalam suatu penelitian percobaan dan mendapat pengobatan dengan AZM dengan dosis 1 gram secara oral sekali sehari selama 5 hari. Biakan darah diulang pada hari ke 6 dan dilakukan biakan dari tinja pada hari ke 6, 7, 8 dan 30 sejak dimulainya pengobatan. Semua pasien mengalami penyembuhan dengan median penurunan panas (sebaran) terjadi setelah 138 (78-228) jam. Tidak dijumpai adanya kekambuhan. Penelitian ini selanjutnya diikuti dengan suatu penelitian perbandingan acak secara terbuka dengan membandingkan AZM dengan dosis oral $1 \mathrm{gram} /$ hari selama 5 hari dibandingkan dengan pemberian ofloksasin $200 \mathrm{mg}$ oral dua kali sehari selama 5 hari. Analisis awal dari 26 penderita dengan biakan darah positif, yang 12 di antaranya mendapat AZM dan 14 mendapat OFL, ternyata $17 / 24(71 \%)$ hasil isolat merupakan MDR, dan 1/24 (4\%) resisten terhadap asam nalidiksat, tetapi tidak dijumpai isolat yang resisten terhadap kedua jenis obat dalam penelitian ini. Semua pasien dalam kedua kelompok pengobatan mengalami penyembuhan. Median (sebaran) jangka waktu penurunan panas masing-masing adalah 126 (60-252) jam untuk AZM dan $99(42-228)$ jam untuk OFL (p=0,08). Semua hasil biakan darah dan tinja yang dilakukan setelah selesai pemberian pengobatan ternyata negatif. Didapatkan gejala gastroenteritis ringan yang tidak memerlukan pengobatan pada kelompok AZM, tetapi tidak terdapat gejala samping yang lain secara bermakna pada kedua kelompok pengobatan. Hasil analisis awal dari penelitian ini menunjukkan bahwa pengobatan selama 5 hari dengan AZM atau OFL keduanya efektif untuk pengobatan DT pada penderita dewasa yang disebabkan oleh S. typhi yang resisten terhadap berbagai jenis obat.
\end{abstract}

\begin{abstract}
In recent years multi-resistant (MDR) strains of Salmonella typhi have emerged in many countries including Vietnam. In Vietnam and the Indian sub-continent isolates of S. typhi resistant to nalidixic acid with a reduced sensitivity to fluoroquinolones have also appeared. Third generation cephalosporins and fluoroquinolones are currently used widely for treating typhoid fever (TF). Azithromycin $(A Z M)$ has moderate in-vitro activity against $\mathrm{S}$. typhi but achieves high intracellular concentrations and has been shown to be effective for treating TF when given for 7 or more days. There have been no randomised comparisons using shorter courses of AZM. Five blood culture positive Vietnamese adults were enrolled in a pilot study and received AZM Igm orally once a day for 5 days. Blood cultures were repeated on day 6 and stool cultures on days $6,7,8$ and 30 days after the start of therapy. All five patients were cured with a median (range) fever clearance time of 138 (78-228) hours. No relapses were detected. An open randomised comparison was therefore commenced comparing AZM $1 \mathrm{gm}$ orally once a day for 5 days versus Ofloxacin $200 \mathrm{mg}$ orally twice a day for 5 days. An interim analysis of the first 26 blood culture positive adults included 12 treated with AZM and 14 with OFL. 17/24 (71\%) of the isolates were MDR, $1 / 24$ (4\%) were nalidixic acid resistant but none were resistant to either of the study drugs. All patients in both groups were cured. The median (range) fever clearence time was 126 (60-252) hours for Azithromycin and 99 (42-228) hours for Ofloxacin ( $p=0.08)$. Cultures of blood and faeces after the end of therapy were negative in all cases. There were mild self limiting gastrointestinal side effects in the AZM treated patients but no other significant side effects attributable to either antibiotic. These interim results suggest that a five day course of AZM or OFL are both effective for the treatment of the TF in adults due to multi-resistant $\mathrm{S}$. typhi.
\end{abstract}

\footnotetext{
'Department of Infectious Diseases, Faculty of Medicine, University of Medicine and Pharmacy, Ho Chi Minh City;

${ }^{2}$ The University of Oxford-Wellcome Trust Clinical Research Unit, Centre for Tropical Diseases, Ho Chi Minh City,

${ }^{3}$ Centre for Tropical Diseases, Ho Chi Minh City, Vietnam
}

\section{INTRODUCTION}

With more than 12.5 million cases occurring each year throughout the world, typhoid fever continues to present a considerable health problem, particularly in developing countries. In recent years, multi-drug resistant strains of Salmonella typhi have emerged in 
many countries including Vietnam ${ }^{1}$. Although fluoroquinolones are used widely for treating these resistant strains their use is relatively contraindicated in children and in pregnancy because of possible adverse effects on cartilage. Furthermore, isolates of $S$. typhi resistant to nalidixid acid with a reduced sensitivity or resistance to fluoroquinolones have appeared in Vietnam and the Indian sub-continent 2,3. Azithromycin, the first of a new class of azalides, has moderate in-vitro activity against $S$. typhi $i^{4}$ but achieves high intracellular concentrations and has been shown to be effective in a murine typhoid caused by Salmonella typhimurium $^{5}$ and for treating typhoid fever when given for 7 or more days ${ }^{6-9}$. There have been no randomised comparisons using courses of azithromycin shorter than 7 days in typhoid. In a pilot study, five Vietnamese adults with blood culture positive TF received azithromycin $1 \mathrm{gm}$ orally once a days for 5 days. All five patients were cured with a median (range) fever clearence time of 138 (78-228) hours. No relapses were detected. A study was therefore commenced to compare the clinical and bacteriological efficacy of a five day course of azithromycin or ofloxacin for the treatment of typhoid fever in adults.

\section{METHODS}

The study was performed on the adult typhoid ward at the Centre for Tropical Diseases, Ho Chi Minh City. The hospital is a 500 bed referral centre for Ho Chi Minh City and the surrounding provinces. The study had received ethical approval from the Scientific and Ethical Committee of the Centre for Tropical Diseases and all patients gave informed verbal consent. Adults (15 years old) with the clinical features of enteric fever and who were blood culture positive with $S$. typhi or $S$. paratyphi A were enrolled in the study. Patients were excluded if they had evidence of severe or complicated disease (coma, shock, visibly jaundiced, gastrointestinal bleeding, intestinal perforation, pneumonia), a history of significant underlying disease, had a previous history of hypersensitivity to either of the trial drugs and had previous treatment with a quinolone or $3^{\text {rd }}$ generation cephalosporin or macrolides within one week of hospital admission and were pregnant. Patients were allocated to one of two treatment groups in an open randomised comparison. The treatment allocation were kept in a sealed envelope which were only opened when the patient had been entered into the study. Patients received either azithromycin $1 \mathrm{gm}$ orally once a day for 5 days or ofloxacin $200 \mathrm{mg}$ orally twice a day for 5 days.
Blood cultures were obtained before therapy and 24 hours after the end of therapy (day 6). Faecal cultures (three specimens) and a urine culture were performed before therapy and faecal cultures were repeated on days $6,7,8$ and 30 after the start of therapy. Isolates of Salmonella were identified by standard biochemical test and agglutination with Salmonella antisera. Antimicrobial sensitivities were performed by the modified Bauer-Kirby method with zone size interpretation based on NCCLS guidelines. Patients in whom $S$. typhi with an intermediate sensitivity to azithromycin were still treated with azithromycin if randomised to that drug. A full blood count, SGOT, SGPT, creatinine and urinalysis were performed before therapy and on day 6 . If the SGOT, SGPT or creatinine were abnormal they were repeated until they had become normal. Chest X-ray and other radiological investigations, including abdominal ultrasound, were performed as clinically indicated. $\mathrm{Pa}-$ tients were examined daily with particular reference to clinical symptoms, fever clearance time, any side effects of the drug and any complication of the disease. The response to treatment was assessed by clinical parameters (resolution of clinical symptoms and signs), fever defervescence (time to first fall bellow $37.5^{\circ} \mathrm{C}$, axillary, and to remain below $37.5^{\circ} \mathrm{C}$ for 24 hours), time to eradication of bacteraemia, development of complications and evidence of relapse of infection.

Treatment failure was defined as the persistence of fever and symptoms for more than five days after the end of treatment or the development of any severe complications. Patients who failed were retreated with ofloxacin $10 \mathrm{mg} / \mathrm{kg}$ per day for 7 to 10 days or ceftriaxone $2 \mathrm{~g}$ /day for 7 to 10 days. Patients were followed up 4 - 6 weeks post treatment. At this time any clinical evidence of relapse was sought, three stool cultures were performed and any abnormal laboratory investigation was repeated. A full set of microbiological cultures were performed if the symptoms and signs suggested further infection.

To detect failure rates of $1 \%$ and $20 \%$ for ofloxacin and azithromycin respectively (80\% power, $5 \%$ significance level), 50 patients will need to be recruited in each group. Proportion were compared with the Chi squared test with Yates' correction or the Fisher's exact test. Non-normally distributed data were compared using the Mann Whitney $U$ test. Statistical analysis was performed using the Staview software package. 
Table 1 Clinical and laboratory features and response to treatment of patients with culture-confirmed of Typhoid fever

\begin{tabular}{|c|c|c|c|}
\hline Features of patients & OFL group $(n=14)$ & AZM group $(n=12)$ & $P$ \\
\hline No. of males / females & $9 / 5$ & $4 / 8$ & $>0.05$ \\
\hline Age (year, median [range]) & $25(16-40)$ & $24(17-37)$ & $>0.05$ \\
\hline Duration of fever before admission (days) & $11.5(7-30)$ & $11.0(5-18)$ & $>0.05$ \\
\hline Admission temp $\left({ }^{\circ} \mathrm{C}\right.$, median [range] $)$ & $39.9(38.0-40.5)$ & $39.4(39.0-40.5)$ & $>0.05$ \\
\hline Hepatomegaly (\%) & 40 & 16.6 & $>0.05$ \\
\hline Splenomegaly (\%) & 6.6 & 8.3 & $>0.05$ \\
\hline White cell count $\left(\times 10^{9} / \mathrm{L}\right)$ & $7.0(4.2-10.0)$ & $5.5(3.1-11.2)$ & 0.05 \\
\hline Hematocrit $\%$ & $38(28-47)$ & $39(30-43)$ & $>0.05$ \\
\hline SGOT (IU/L, mean [range]) & $75(25-294)$ & $105(31-169)$ & $>0.05$ \\
\hline SGPT (IU/L, mean [range]) & $71(22-237)$ & $64(21-136)$ & $>0.05$ \\
\hline \multicolumn{4}{|l|}{ Organism isolated } \\
\hline S. typhi & 14 & 12 & \\
\hline Multi-resistant (\%) & $10(71)$ & $7(58)$ & \\
\hline Nalidixic acid resistant & $0(0)$ & $1(8)$ & \\
\hline Treatment failures & 0 & 0 & \\
\hline Acute complications & 0 & 0 & \\
\hline Microbiological relapse & 0 & 0 & \\
\hline Fever clearance time (hours, median [range]) & $99(42-228)$ & $126(60-252)$ & 0.08 \\
\hline \multicolumn{4}{|l|}{ Duration of admission after starting treatment } \\
\hline (days, median [range]) & $11(7-16)$ & $12(10-17)$ & 0.06 \\
\hline Side effects & none & Nausea : 2 & \\
\hline & & Diarrhoea : 3 & \\
\hline
\end{tabular}

\section{RESULTS}

An interim analysis of the first 26 blood culture positive adults included 12 treated with azithromycin and 14 with ofloxacin. S. typhi was isolated from all of the blood cultures and $8 / 26(31 \%)$ of the patients had at least one positive pre-treatment faecal culture. All isolates were sensitive to ofloxacin although $1 / 26$ was resistant to nalidixic acid. None of the isolates were resistant to azithromycin although $8 / 26(31 \%)$ (3 randomised to azithromycin) were of intermediate sensitivity on the basis of the zone size. The demographic, clinical and laboratory findings for the culture confirmed cases of typhoid fever are shown in the Table 1 . There were no important differences between the admission characteristics of the two groups. There were no treatment failure in either group. Cultures of blood and faeces after the end of therapy were negative in all cases. Mild self limiting gastrointestinal side effects were seen in five of azithromycin treated patients but there were no other significant side effects attributable to either antibiotic. No relapses were detected.

\section{DISCUSSION}

Since 1991 S. typhi resistant to all the conventional first-line antibiotics, ampicillin, cotrimoxazole and chloramphenicol, has been reported from Central and South America, the Middle East, the Indian Sub-continent and South East Asia. In Vietnam by 1996 the proportion of multi-resistant strains isolated from blood cultures at this centre increased to over $80 \%$. Furthermore, strains with resistance to nalidixic acid and reduced sensitivity to the fluoroquinolones, have emerged ${ }^{2}$. Third generation cephalosporins and fluoroquinolones are currently used widely for treating multi-resistant typhoid fever in many countries. In Vietnam randomised comparative studies of fluoroquinolones (fleroxacin and ofloxacin) and ceftriaxone in adults have shown the fluoroquinolones to be superior. Ceftriaxone given for three or five days gave clinical and microbiological cure rates of $72-87 \%$ and $92-93 \%$ respectively 9,10 . With fluoroquinolones (ofloxacin or fleroxacin used for 2,3 or 5 days) the cure rates were 97-100\% and 99-100\%10-14. The results of treatment with fluoroquinolones were 
significantly worse, however, in patients infected with isolates of $S$. typhi resistant to nalidixic acid and reduced sensitivity to fluoroquinolones. When treated with ofloxacin for 2 to 3 days patients infected with nalidixic acid resistant $S$. typhi had a significantly longer fever clearance time compared with patients infected with a nalidixic acid sensitive isolated and had 44 fold increased risk of needing a further course of antibiotic ${ }^{2}$. The study of new drugs for treating multi-resistant S.typhi is therefore important.

Azithromycin, the first of a new class of azalides, has moderate activity against S.typhi. The reported S.typhi activity of azithromycin against $S$. typhi (MIC 90 $8 \mathrm{mg} / \mathrm{L}$, Range $2-16 \mathrm{mg} / \mathrm{L})^{4}$ is above the reported peak serum level of azithromycin following a $500 \mathrm{mg}$ dose of $0.4 \mathrm{mg} / \mathrm{L} 15$ Azithromycin, however, is concentrated in the tissues 50 to 100 fold compared with the serum levels and achieves high intracellular concentrations. In a murine model of salmonellosis it was found to be highly active ${ }^{4}$. This discordance between in-vitro susceptibility and in-vivo effectiveness is probably explained by the fact that. S.typhi is predominantly an intracellular pathogen.

Azithromycin $500 \mathrm{mg}$ once daily for between 7 and 14 days was found to be effective in adults with typhoid fever in Chile. The fever clearance time was 5.4 days for 5 patients treated for 14 days and 4.8 days for 5 patients treated for 7 days. In an open study in Cairo, 14 patients received azithromycin as a single dose $1 \mathrm{~g}$ on the first day, followed by $500 \mathrm{mg}$ for 6 additional days were cured with a fever clearance of 4.3 days $^{6}$. In these two studies $3 / 24$ (13\%) of patients were still blood culture positive at day 4 . In a study in Bahrain three of four adults failed azithromycin given as $1 \mathrm{gm}$ on day one and then 500 $\mathrm{mg}$ a day for the next six days ${ }^{16}$. The three failures had clinically deteriorated by day four or five of therapy and one was blood culture positive on day four. Comparative studies in Cairo of azithromycin ( $1 \mathrm{gm}$ on day $1,500 \mathrm{mg}$ a day for the next 6 days) in 16 adults and ciprofloxacin (500 mg twice daily for 7 days) in 17 adults cured all patients and gave a fever clearance of 4.1 and 3.6 days respectively 7 . In a similar study in India comparing azithromycin $500 \mathrm{mg}$ a day for 7 days with chloramphenicol 2-3 g per day for 14 days was $88 \%$ clinically and $100 \%$ microbiologically successful in 42 adults treated with azithromycin and $86 \%$ and $94 \%$ successful in 35 adults treated with chloramphenicol8.
We wished to use a five day course of azithromycin both to be comparable to the five day course of ofloxacin which is widely used for nalidixic acid sensitive isolates in Vietnam and to ensure compliance. However we were concerned about the reports of the blood cultures remaining positive after 4 days of treatment with the standard regimen. Furthermore our studies of the localisation of bacteria in the blood of patients with typhoid have shown that many of the bacteria are in fact extracellular [Wain J, unpublished observations]. Doses of azithromycin higher than the recommended $5-10 \mathrm{mg} / \mathrm{kg}$ have been tolerated 17,18 . We therefore investigated the efficacy and tolerability of a short course high dose regimen. This interim analysis has shown that the clinical and microbiological and cure rate with azithromycin was $100 \%$ and the fever clearance time of 5.2 days was comparable to the other studies. Apart from some mild side effect with nausea, vomiting and diarrhoea, the azithromycin was well tolerated. In this study three patients randomised to azithromycin had strains with intermediate sensitivity to azithromycin on the basis of disc zone size. All of them had a good response to azithromycin with fever clearances of 60, 138 and 162 hours. Ofloxacin in a course of five days was also $100 \%$ effective with a fever clearance time comparable to a previous study. All of the patients randomised to receive ofloxacin had nalidixic acid sensitive isolate.

Our interim results therefore suggest that a five day course of azithromycin or ofloxacin are both effetive for treating typhoid fever in adults in an area with a high incidence of multi drug resistant typhoid fever.

\section{REEFERENCES}

1. White NJ and Parry CM. The treatment of typhoid fever. Curr Opin Infect Dis 1996; 9: 298-302.

2. Wain J, Hoa N'TT, Chinh NT, Vinh H, Everett MJ, Diep TS et al. Quinolone-resistant Salmonella typhi in Vietnam : Molecular basis of resistance to treatment. Clin Infect Dis 1997; 25(in press).

3. Brown JC, Shanahan PMA, Jesudason MV, Thomson CJ, Aymes SGB. Mutations responsible for reduced suspectibility to 4-quionolones in clinical isolates of multi-resistant Salmonella typhi in India. J Antimicrob Chemother 1996; 37: 891900

4. Methock B. In-vitro activity of azithromycin compared with other macrolides and oral antibiotics against Salmonella typhi. J Antimicrob Chemother 25 (Suppl A): 29-31.

5. Butler T, Girard AE. Comparative efficacies of azithromycin and ciprofloxacin againts experimental Salmonella typhimurium Infection in mice. J Antimicrob Chemother 1993; 31: 313-9. 
6. Butler T, Palomino C, Johnson RB, Hopkins SJ. Efficacy of azithromycin for treatment of typhoid fever [abstract 1579]. In: Program and abstracts of the $32^{\text {nd }}$ Interscience Conference on Antimicrobial Agents and Chemotherapy (Anaheim, California).Washington DC: American Society for Microbiology 1992.

7. Tribble D, Girgis N, Habib N, butler T. Efficacy of azithromycin for typhoid fever. Clin Infect Dis 1995; 21:1045-6.

8. Girgis NI, Brown FM, Butler T and Tribble T. Randomised trial of azithromycin (AZM) vs.ciprofloxacin (CIP) for treatment of typhoid fever [abstract 12.001]. In: Abstract of the $7^{\text {th }}$ International Congress for Infectious Diseases, Hong Kong 1996.

9. Butler T, Sridhar C, Daga M, Jani K, Pandit R, Khakhria R, Potkar C and Johnson R. Azithromycin vs. Chloramphenicol in the treatment of typhoid fever in India. [Abstract LM-18]. In Program and Abstract of the $37^{\text {th }}$ Interscience Conference on Antimicrobial Agents and Chemotherapy (Toronto, Canada). Washington DC: American Society for Microbiology.

10. Hien TT, Duong NM, Ha HD, Hoa NTT, Diep TS, Phi Lt and Arnold K. A randomised.comparative study of fleroxacin and cefriaxone in enteric fever. Trans Roy Soc Trop Med Hyg 1994; 88: 464-5.

11. Smith MD, Duong MD, Hoa NTT, Wain J, Diep TS, Day NPJ, Hien TT and White NJ. Comparison of ofloxacin and ceftriaxone for short-course treatment of enteric fever. AntimicrobAgents Chemother 1994; 38: 1716-20.

12. Hien TT, Bethell DB, Hoa NTT, Wain J, Diep TS, Phi LT et al Short course of ofloxacin for treatment of typhoid multidrug resistant typhoid. Clin Infect Dis 1995; 20: 917-23.

13. Duong NM, Vinh Chau NV, Van Anh DC, Hoa NTT, Hoai Tam DT, Ho VA et al. Short course fleroxacin in the treatment of typhoid fever. JAMA Southeast Asia 1995; 11: 21-5.

14. Chish NT, Solomon T, Thong MX, Ly NT, Hoa NTT, Wain $\mathrm{J}$ et al. Short course of ofloxacin for the treatment of enteric fever. Trans Roy Soc Trop Med Hyg 1997; 91: 347-9.

15. Foulds G, Shepard RM, Johnson RB. The pharmacokinetics of azithromycin in human serum and tissues $J$ Antimicrob Chemother 1990; 25(Suppl A): 73-82.

16. Wallace MR, Yousif AA, Habib NF, Tribble DR. Azithromycin and typhoid. Lancet 1994; 343: 1497-8.

17. O'Doherty B. Azithromycin versus penicillin $\mathrm{V}$ in the treatment of paediatric patients with acute streptococcal pharyngitis/tonsillitis. Paediatric azithromycin study group. Eur J Clin Microbiol Infect Dis 1996; 15: 7I8-24.

18. Luke DR, Foulds G, Cohen SF, Levy B. Safety, tolcration and pharmacokinetics of intravenous azithromycin. Antimicrob Agents Chemother 1996; 40: 2577-681. 